INTERNATIONAL JOURNAL OF RESEARCHES IN BIOSCIENCES, AGRICULTURE AND TECHNOLOGY

(c) VISHWASHANTI MULTIPURPOSE SOCIETY (Global Peace Multipurpose Society) R. No. MH-659/13(N) www.ijrbat.in

\title{
EFFECT OF POLLUTED AIR ON FRESH AND EXPOSED POLLEN OF RICINUS COMMUNIS L. FROM NAGPUR (M.S.)
}

\author{
Gunjekar, S.S. and Kalkar, S.A. \\ Department of Botany, Shri Mathuradas Mohota College of Science, Nagpur. \\ Department of Botany, Institute of Science Nagpur - 440001 (M.S.) \\ shraddha.gunjekar@gmail.com, surekhakalkar@gmail.com
}

\begin{abstract}
:
Effects of air pollutants on fresh and exposed pollen grain of Ricinus communis L. were studied in area of Nagpur. In order to study the impact of air pollutants, pollen grains were subjected to LM and SEM (light and scanning electron microscopic studies). LM studies revealed that pollen grains appeared prolate spheroidal, circular polar outline, elliptic equatorial outline, tricozocolporate, costate - vestibulate. Colpi narrowly elliptic, tapering, tips acute, exine thick. Whereas in exposed pollen grains, shrinkage in its size and breakage of exine was noticed. SEM studies of exposed pollen shown some particulate matter was attached to its surface. The studies have discussed the structural changes in pollen characteristics of Ricinus communis L. under the influence of air pollutants.
\end{abstract}

Keywords: Pollen morphology, LM, SEM, Air pollutants

\section{INTRODUCTION:}

Now-a-days air pollution is one of the major problems. Harmful emission from various types of industries and gaseous pollutant released in the atmosphere by it are not only harmful for human health but also affects plants in many ways.

It has been reported that air pollution changes both the structure and development of anthers, leading to an increased number of deformed pollen grains as compared to control samples. Apertures were closed and microspores of exine sculpturing were found to be bigger and more fragile. Airborne particle materials adhere to the pollen surface, causing the collapse and degradation of the exine surface, and shrinkage and abnormality of pollen (Majd \& Mohamadi, 1992; Emberlin, 1998; Parui et al., 1998; Pelter, 1998).

Ricinus communis L. is a tall, evergreen shrub, found throughout India, mostly growing on waste land and cultivated for seeds oil. Leaves alternate, petiolate, broad, palmately, 5-11 lobed, peltate, orbicular are green or reddish-green, broad, palmately lobed, lobes oblong linear, acute, margin serrate. Flower greenish white or reddish, monoecious in terminal panicales. Flowers are pedicellate, bracteates, unisexual, monoecious, male flower towards lower portion, female flowers towards apical portion of inflorescence. The male flowers are yellowish green with prominent creamy stamens and are carried in ovoid spikes up to $15 \mathrm{~cm}$ long. The female flowers borne at the spike have prominent red stigmas. Capsule globose covered with brown. Seeds oblong, grey, mottled with brown, shining.

The present study was undertaken to reveal the pollen morphological variations using LM and SEM so as to understand palynological characteristics within fresh and exposed pollen grains of Ricinus communis L. in order to study the effect of air pollutant on pollen which is responsible to cause pollen allergy.

\section{METHOD AND MATERIAL:}

LM studies- Light microscopic studies were carried out by acetolysis method (Erdtman, 1952).

SEM Studies: Scanning Electron Microscopy of pollen grains of fresh and exposed area carried out at VNIT, Nagpur.

\section{RESULT AND DISCUSSION:}

LM studies revealed that pollen grains appeared prolate spheroidal, circular polar outline, elliptic equatorial outline, tricozocolporate, costate vestibulate. Colpi narrowly elliptic, tapering, tips acute, exine thick. As per SEM analysis, pollen 
grains prolate spheroidal, pollen grain diameter is $24.3 \mu \mathrm{m}$ in fresh pollen grain and $21.9 \mu \mathrm{m}$ in exposed pollen grain, cirular polar outline, elliptic equatorial outline, trizonocolporate, costatevestibulate. Length / breadth are $33.5 \mathrm{\mu m} /$ $22.3 \mu \mathrm{m}$ in fresh and $30.2 \mu \mathrm{m} / 20.3 \mu \mathrm{m}$ and exposed pollen grains. Pore size is $227 \mathrm{~nm}$ in fresh pollen grain and $215 \mathrm{~nm}$ in exposed pollen grain. Colpi narrowly elliptic, wide at equator, sides tapering, tips acute, exine thick, sculpturing psilate. Pollen grains and fungal spores are the most predominant allergen in the air (Kalkar and Patil, 1994; Kalkaret. al., 1998). The morphological studies of the pollen are very important. It is also applicable in genetic study, forensic science in tracing history of vegetation, which consists of individual species, community and climate change study (Aftab and Perveen, 2006).

Pollen grains represent the male reproductive unit and hence plays key role in reproduction and growth of plants. The objective of present study was to assess the air pollution effects through palynological studies. The present study focus light on impact of air pollution on pollen grains and found the structural changes due to pollution, which in turn will harm its metabolic processes.

Effects of air pollutants on fresh and exposed pollengrain of RicinuscommunisL. were studied in area of Nagpur. In order to study the impact of air pollutants, pollen grains were subjected to LM and SEM (light and scanning electron microscopic studies).The studies have discussed the structural changes in pollen characteristics of RicinuscommunisL. under the influence of air pollutants.

\section{CONCLUSION:}

Morphological and SEM studies are important as they are helpful to understand details of mechanism of pollination, in vivo germination and for hybridization experiments. These studies are also helpful in plant taxonomy, embryology, phytochemistry and biotechnology. (Bediet al, 2008).

\section{Acknowledgement}

Author is thankful to Director, Institute of Science Nagpur and VNIT, Nagpur for providing laboratory and SEM facilities.

\section{REFERANCE :}

Aftab, R. And Perveen, A. 2006. A palynological study of some cultivated trees from Karachi. Pak. J. Bot.38(1): 15-28.

Bedi S, Tanuja, Vyas S.P. 2008. A handbook of aromatic and essential oil plants.Agrobios, Jodhpur (India)

Emberlin, J. 1998. The effects of air pollution on allergenic pollen.EurRespir Rev8: 164-1672.

Erdtman, G.1952. Pollen morphology and Plant taxonomy- Angiosperms.Almquist\&Wicksell, Stockholm

Kalkar, S. A. and Patil, G. V. 1994. Airborne biocomponents in the air of Nagpu.J.Aerobiol., Vol. 7 pp.1-7.

Kalkar, S.A. and Patil, G. V. 1998.Aero allergens at Nagpur.BotaniqueSpl Comm.Vol XI p.p. 52-55.

Majd, A. \&Mohamadi, S. 1992. Effect of certain toxins and air pollution on pollen development of Glycinemax . J Islamic Azad University 649651. 


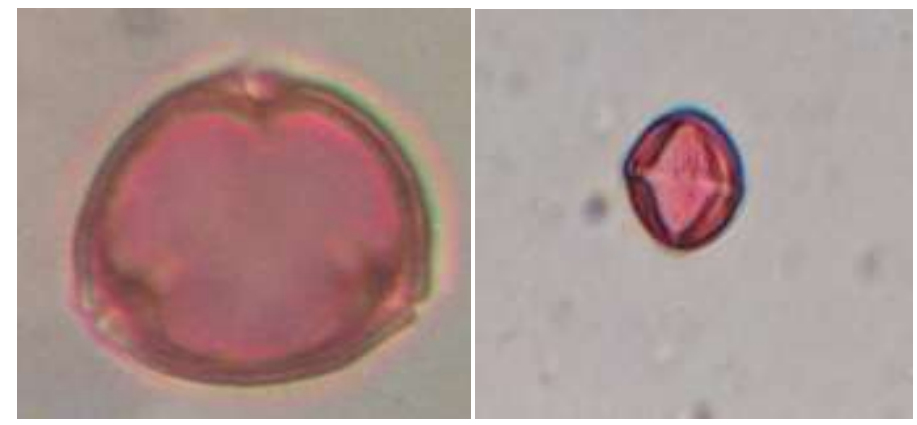

Fig 1: LM Fresh pollen grain of Ricinus communisL.Fig.2: LM- Exposed pollen grains of RicinuscommunisL.

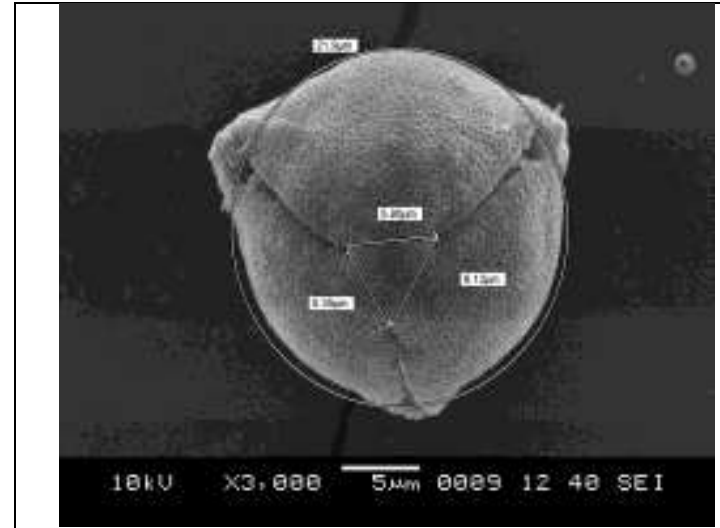

Fig3: Fresh pollen grain of Ricinus communis

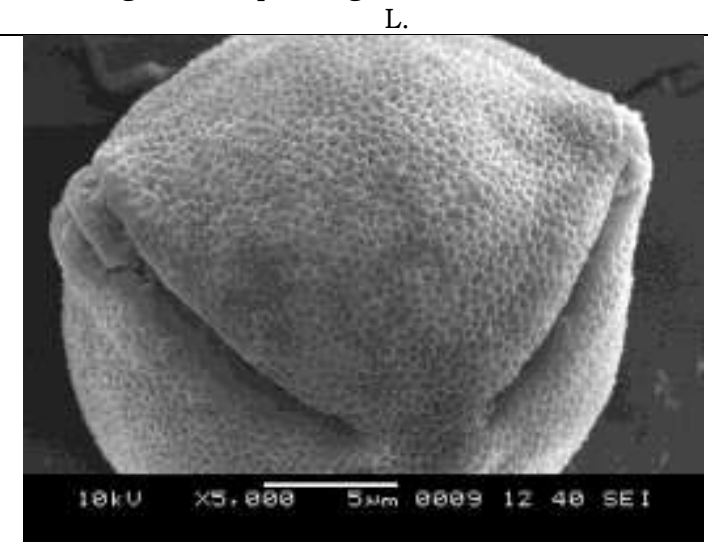

Fig 5: Fresh pollen grain of Ricinus communis L.

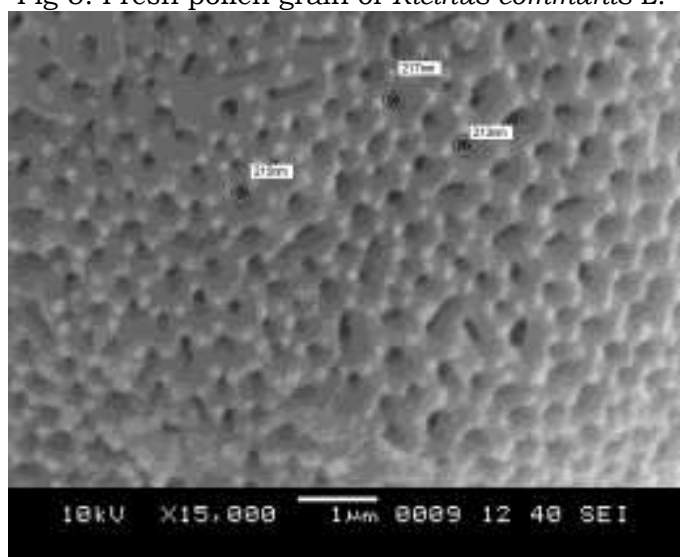

Fig 7: Pollen wall showing pores of fresh pollen grain of Ricinus communis L.

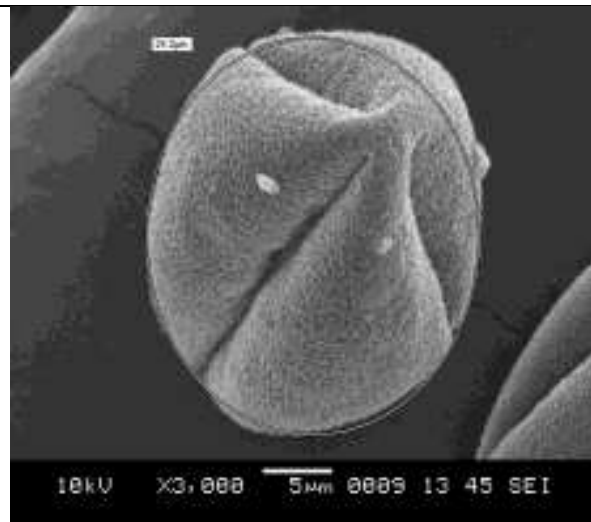

Fig 4:Exposed pollen grain of Ricinus communis L.

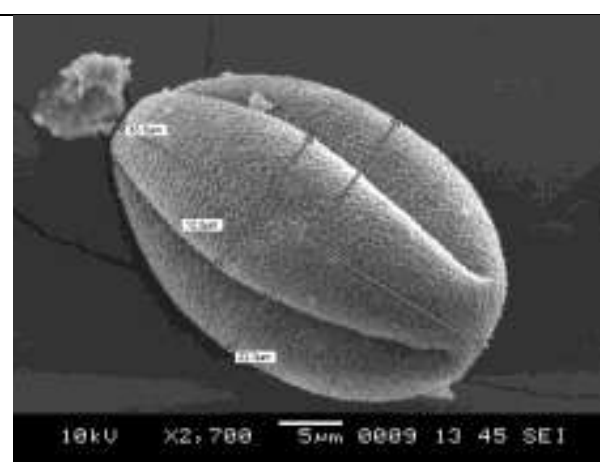

Fig 6: Exposed pollen grain of Ricinus communis L.

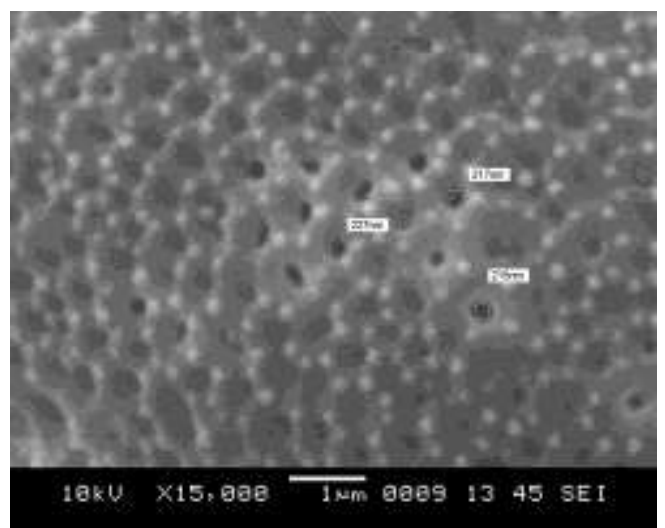

Fig 8 :Pollen wall showing pores of exposed pollen grain of Ricinus communis L. 